\title{
Procedures' costs related to outpatient chemotherapy treatment of women suffering from breast cancer
}

\author{
CUSTO DE PROCEDIMENTOS RELACIONADOS AO TRATAMENTO QUIMIOTERÁPICO \\ AMBULATORIAL DE MULHERES PORTADORAS DE CÂNCER DE MAMA
}

\author{
COSTO DE LOS PROCEDIMIENTOS RELACIONADOS CON EL TRATAMIENTO DE \\ QUIMIOTERAPIA AMBULATORIA PARA MUJERES CON CÁNCER DE MAMA
}

\section{Caroline Rife Nobrega ${ }^{1}$, Antônio Fernandes Costa Lima²}

\begin{abstract}
Objective: To identify the direct cost of procedures related to an outpatient chemotherapy treatment for women with breast cancer. Method: This is a quantitative research, using the case study methodology, performed in an outpatient chemotherapy of a private hospital. The total cost was calculated by multiplying the time spent by professionals involved in therapeutic procedures, the unit cost of direct labor, adding to the cost of materials, drugs and solutions. For performing the calculations, we used the Brazilian currency (R\$). Results: The average total cost per chemotherapy session corresponded to $\mathrm{R} \$ 1,783.01$ (100\%), being $\mathrm{R} \$ 1,671.66$ $(93.75 \%)$ spent with drugs, $\mathrm{R} \$ 74,98$ (4.21\%) with materials, $\mathrm{R} \$ 28.49$ (1.60\%) with labor and $\mathrm{R} \$ 7.88$ (0.44\%) with solutions. Conclusion: The results may support discussions and decision making for the management of costs related to chemotherapy aimed at reducing expenses and eliminating waste without harm to the care provided.
\end{abstract}

\section{RESUMO}

Objetivo: Identificar o custo direto de procedimentos relacionados ao tratamento quimioterápico ambulatorial de mulheres portadoras de câncer de mama. Método: Pesquisa quantitativa, do tipo estudo de caso, realizada no ambulatório de quimioterapia de um hospital privado. O custo total foi calculado multiplicando-se o tempo despendido pelos profissionais envolvidos nos procedimentos terapêuticos, pelo custo unitário da mão de obra direta, somando-se ao custo dos materiais, fármacos e soluções. Para a realização dos cálculos, utilizou-se a moeda brasileira (R\$). Resultados: O custo total médio, por sessão de quimioterapia, correspondeu a $\mathrm{R} \$ 1.783,01(100 \%)$, sendo $\mathrm{R} \$ 1.671,66$ (93,75\%) com fármacos, $\mathrm{R} \$ 74,98(4,21 \%)$ com materiais, $\mathrm{R} \$ 28,49(1,60 \%)$ com mão de obra e $R \$ 7,88(0,44 \%)$ com soluções. Conclusão: Os resultados obtidos poderão subsidiar discussões e tomadas de decisões em relação à gestão dos custos relativos à quimioterapia visando à redução dos gastos e a eliminação dos desperdícios, sem prejuízos ao atendimento prestado.

\author{
DESCRITORES \\ Neoplasias da mama \\ Quimioterapia \\ Custos de cuidados de saúde \\ Custos e análise de custo \\ Enfermagem oncológica
}

\section{RESUMEN}

Objetivo: Identificar el costo directo de los procedimientos relacionados con el tratamiento de quimioterapia ambulatoria para las mujeres con cáncer de mama. Método: Investigación cuantitativa, del tipo de estudio de caso, realizada en el ambulatorio de quimioterapia de un hospital privado Se calculó el costo total mediante la multiplicación del tiempo dedicado por los profesionales involucrados en el proceso, por el costo unitario de la mano de obra directa, sumándose al costo de los materiales, fármacos y soluciones. Para la realización de los cálculos se utilizó la moneda brasileña (R\$). Resultados: El costo total medio, por sesión de quimioterapia, correspondió a $\mathrm{R} \$$ $1.783,01$ (100\%), de los cuales $R \$ 1.671,66$ $(93,75 \%)$ fueron con fármacos, $R \$ 74,98$ $(4,21 \%)$ con materiales, $\mathrm{R} \$ 28,49(1,60 \%)$ con mano de obra y $R \$ 7,88(0,44 \%)$ con soluciones. Conclusión: Los resultados logrados podrán servir como base para las discusiones y la toma de decisiones con respecto a la gestión de los costos relacionados con la quimioterapia, con vistas a la reducción de los gastos y la eliminación de los desperdicios, sin perjuicios a la atención prestada.

\section{DESCRIPTORES}

Neoplasias de la mama

Quimioterapia

Costos de la Atención en Salud

Costos y análisis de costo

Enfermería oncológica.

${ }^{1}$ Master of Science, School of Nursing, University of São Paulo, São Paulo, SP, Brazil. ${ }^{2}$ PhD professor, Department of Professional Orientation, School of Nursing, University of São Paulo, São Paulo, SP, Brazil. 


\section{INTRODUÇÃO}

Questions regarding costs for the treatment of cancer have been one of the agendas of discussions in many countries. The American Society of Clinical Oncology (AS$\mathrm{CO})$, considering the high cost that involves this type of treatment and the inability of many Americans to perform them, have developed strategies to discuss the factors that contribute to rising costs. According to the $\mathrm{ASCO}^{(1)}$, high quality cancer treatment will be increasingly less accessible to an increasing number of cancer patients, unless actions are taken to reverse current trends, which have intensified concern about the financial aspects.

Anticancer treatments represent a high cost for the Brazilian health systems, both for the Unified Health System (SUS) as for the Supplementary Health System (SHS) ${ }^{(2)}$. SHS managers recognize that the cost of antineoplastic therapy has been growing alarmingly and seek alternatives to minimize its costs ${ }^{(3)}$.

American study addressing the costs of health care for patients with metastatic breast cancer showed that chemotherapy throughout 18 months represented $25 \%$ of total costs, totaling U\$ 128.556 dollars per patient ${ }^{(4)}$.

In relation to chemotherapy of breast cancer, a single drug may be used or several of them associated with the choice of anticancer regimens, such as CMF (Cyclophosphamide, Methotrexate and Fluorouracil); DCP (Doxorubicin, Cyclophosphamide and Paclitaxel); FEC (Fluorouracil, Epirubicin and Cyclophosphamide) and FDC (Fluorouracil, Doxorubicin and Cyclophosphamide) ${ }^{(5)}$. However, it is worth noting that although there are frequently used regimens, there are numerous possible combinations between the various antineoplastic availability ${ }^{(6)}$.

In Brazil, there are few studies addressing costs in the area of Oncology, a complex discipline that combines therapeutic procedures using high technology and skilled labor in order to improve the quality of life and survival rates of cancer patients. To contribute to the development of knowledge in this thematic, the present study aimed to identify the average total cost procedures related to outpatient chemotherapy for women with breast cancer at a private hospital.

\section{METHOD}

This is a quantitative, exploratory, descriptive, case study type ${ }^{(7)}$, conducted in an Outpatient Chemotherapy clinic in a private hospital of large size, in the city of São Paulo (SP), Brazil, which currently holds, most frequently, the treatment of individuals with breast and bowel cancers.

The hospital has an Outpatient Unit for Social Sustainability in order to host the project management in partnership with the Ministry of Health $(\mathrm{MH})$ and serve public patients. Thus, patients with breast cancer may come from this unit, from health insurance companies or private payment.
The outpatient clinic is open from 8:00am to 6:00pm, Monday through Friday and serves an average of 25 patients per day. The health care team consists of six medical oncologists, four nurses, two pharmaceutical professionals, one nursing technician and a pharmacy assistant.

The most commonly used anticancer regimens are CMF; DCP; FDC and FEC, they may use various other combinations of drugs, for instance, Docetaxel, Trastuzumab, Bevacizumab, Gemcitabine and Vinorelbined. The applications of the regimes and combinations of drugs can be weekly, with intervals of 21 or 28 days.

The procedures related to chemotherapy treatment, that composed this study, were: separation, preparation and disposal of chemotherapeutics (first stage); separation and disposal venipuncture materials and pre-medication (second stage); preparation and administration of pre-medication (third stage); administration of chemotherapeutics (fourth stage) and removal of vascular access/disposal of chemotherapeutic wastes (fifth stage). Due to limitation of time for conducting the study, it was not possible to observe the stage surveillance of nurses during the administration of chemotherapy.

At the Outpatient Clinic, the working process of the pharmaceutical professional comprises the preparation and disposal of chemotherapeutics, and the pharmacy assistant should separate and dispense venipuncture materials and pre-medications (antihistamines, antiemetics, and corticosteroids). It is the responsibility of nurses and nursing technicians, the preparation of pre-medication, puncture of peripheral venous access and administration of pre-medication. However, it belongs exclusively to nurses puncture of central access port-a-cath and the administration of chemotherapeutics.

The sample was based on convenience, non-probability, and corresponded to 60 horizontal observations from the first to the fifth stage, conducted from November 2012 to March 2013.

To subsidize the cost calculation per chemotherapy session, the consumption of materials, drugs and solutions were documented, as well as the category, the number of professionals involved and the time spent in each process steps. The time spent by these professionals was recorded using a stopwatch.

We calculated the unit cost of direct labor from the average salaries provided by the Human Resources Hospital Department, being: pharmaceutical professional - $R \$ 5,994.91$ ( $R \$$ 0.57/minute); pharmacy assistant - $\mathrm{R} \$ 2,118.75$ ( $R \$$ 0.20 /minute); Nurse - R\$ 8,786.72 (R\$ 0.92/minute) and nursing technician - $\mathrm{R} \$ 5,823.29$ (R\$ 0.61/minute).

Costs were measured using the direct costs, which can be clearly identified and quantified ${ }^{(8)}$. Then, we calculated the average total cost per chemotherapy session, by multiplying the time spent (timed) by professionals at a unit 
cost of direct labor, adding to the cost of materials, drugs and solutions. For performing the calculations, we used the Brazilian currency ${ }^{1}(R \$)$.

The study was approved by the Ethics and Research Committee of the School of Nursing, University of São Paulo (CAAE: 06246612.7.0000.5392; Review: 123,161) and the Hospital field of study (CAAE: 06246612.7.0000.5392; Review: 129,104).

\section{RESULTS}

The observed procedures were related to 32 women, aged $39-88$ years, mean age 56.95 (SD \pm 9.88 ), mode of 58 years ( $95 \% \mathrm{Cl}: 54.40-59.50)$. The observation of a single patient ranged from one to six times, one (56.25\%) and two $(25 \%)$ times the most frequent occurrences.

In the first step: separation, preparation and disposal of chemotherapeutics, the most used drugs were Paclitaxel $(41.67 \%)$ and the antineoplastic regimen Doxorubicin + Cyclophosphamide (35\%). It is evident that Trastuzumab (unit value of $R \$ 8,441.67$ ) and Paclitaxel (unit value of $R \$ 673.34$ - 100mg and $R \$ 344.95$-30mg) represented the most significant values for the composition of the cost items.

Among the materials used, the Neutrapur equipment had the highest unit cost ( $R \$ 52.39$ ), a unit has been used in 26 of 60 observations. As for the solutions (distilled water, water for injection, saline solution), none showed significant unit value.

The duration of the first stage ranged from 6.49 to 43.04 minutes with a mean of 15.15 (SD \pm 6.84 ). In Table 1 , we found that the average total cost was $R \$ 1,673.35$ (100\%), being $0.52 \%$ with pharmaceutical labor, $2.17 \%$ with materials , $0.20 \%$ with solutions and $97.11 \%$ with drugs.

The second stage - disposal of pre-medications - obtained the minimum duration of 1.15 minutes and maximum of 8.18 minutes, mean 3.38 (SD \pm 1.56 minutes). The cost of direct labor of pharmacy assistant, single professional who participated in this stage ranged from $\mathrm{R} \$ 0.23$ to $R \$ 1.64$, and the average total cost of $R \$ 0.68$ (SD \pm 0.31 ).

Table 1 - Distribution of observations on the first stage: separation, preparation and disposal of chemotherapeutics according to personnel costs, materials, solutions and drugs - São Paulo, SP, Brazil, 2013

\begin{tabular}{|c|c|c|c|c|c|c|}
\hline Observations & $\mathbf{n}$ & Mean & $\mathbf{S D} \pm$ & Min & $\operatorname{Max}$ & Mode \\
\hline $\begin{array}{l}\text { Direct labor } \\
\text { cost - pharma- } \\
\text { ceutical }\end{array}$ & 60 & 8.64 & 3.9 & 3.7 & 24.53 & $\ldots$ \\
\hline $\begin{array}{l}\text { Materials' } \\
\text { cost }\end{array}$ & 60 & 36.39 & 31.84 & 4.33 & 74.95 & 72.33 \\
\hline $\begin{array}{l}\text { Solutions' } \\
\text { cost }\end{array}$ & 60 & 3.29 & 1.4 & 1.56 & 5.28 & 2.07 \\
\hline Drugs' cost & 60 & 1625.03 & 2771.53 & 74.4 & 9316.93 & 1077.18 \\
\hline Total Cost & 60 & 1673.35 & 2765.4 & 99.38 & 9407.56 & $\ldots$ \\
\hline
\end{tabular}

${ }^{1}$ One Real $(\mathrm{R} \$)$ corresponded, at the time this paper was written (July of 2014), to U\$ 0,45 American cents.

In the third stage, the duration of the preparation of premedication technique performed by nurses (33 observations) ranged from 4.24 to 15.07 minutes with a mean of 8.06 (SD \pm 2.33$)$, and duration of preparations made by nurses (27 observations) ranged from 1.27 to 11.47 minutes with a mean of 6.06 (SD \pm 2.32 ). Regarding the duration of administration of pre-medication technique performed by nurses (27 observations), there was a variation from 2.44 to 13.20 minutes with a mean of $5.87(\mathrm{SD} \pm 2.50)$, and duration of administrations performed by nurses (33 observations) ranged from 3.47 to 24.00 minutes with a mean of 9.29 (SD \pm 3.93 ).

The duration of the fourth stage, administration of chemotherapeutics, applied by nurses, ranged from 1.46 to 21.50 minutes with a mean of 4.12 ( $S D \pm 2.77$ minutes). The only material considered for the calculation of direct costs related to the 60 observations were examination gloves, with an average value of $\mathrm{R} \$ 0.40$.

Table 2 - Distribution of observations on the stage, preparation and administration of pre medications according to personnel costs, materials, solutions and drugs - São Paulo, SP, Brazil, 2013

\begin{tabular}{lcccccc}
\hline Observations & $\mathbf{n}$ & Mean & SD \pm & Min & Max & Mode \\
\hline $\begin{array}{l}\text { Direct labor cost }- \\
\text { preparation }\end{array}$ & 60 & 5.22 & 1.79 & 1.17 & 10.55 & $\ldots$ \\
\hline $\begin{array}{l}\text { Direct labor cost }- \\
\text { administration }\end{array}$ & 60 & 6.37 & 3.82 & 1.49 & 22.08 & $\ldots$ \\
\hline $\begin{array}{l}\text { Direct labor cost }- \\
\begin{array}{l}\text { Total (preparation } \\
\text { and administration) }\end{array}\end{array}$ & 60 & 11.59 & 4.67 & 5.15 & 28.92 & $\ldots$ \\
\hline Materials' cost & 60 & 37.39 & 13.79 & 17.39 & 76.61 & 25.17 \\
\hline Solutions' cost & 60 & 4.47 & 1.77 & 1.46 & 7.02 & 2.92 \\
\hline Drugs' cost & 56 & 47.1 & 55.07 & 4.54 & 205.36 & 28.54 \\
\hline Total Cost & 60 & 97.41 & 58.13 & 26.29 & 278.47 & $\ldots$ \\
\hline
\end{tabular}

There was variation in the cost of direct labor of nurses between $\mathrm{R} \$ 1.34$ and $\mathrm{R} \$ 19.78$ with an average of $\mathrm{R} \$ 3.79(\mathrm{SD} \pm 2.55)$. The average total cost relating to this stage was $\mathrm{R} \$ 4.19(\mathrm{SD} \pm 2.55)$, and $90.45 \%$ with labor and materials with $9.55 \%$.

The duration of the last stage of venous access and disposal of chemotherapeutic wastes ranged from 2.05 to 8.00 minutes for nurses (51 observations), with a mean of $4.42(S D \pm 1.50)$ and 2.47 in 6.20 minutes for nursing technician (nine observations), with a mean of 3.71 (SD \pm 1.39$)$.

Table 3 - Distribution of observations relating to the removal of vascular access and disposal of chemotherapeutic wastes according to duration, personnel costs, materials, solutions and drugs - São Paulo, SP, Brazil, 2013

\begin{tabular}{lllllll}
\hline Observations & n & Mean & SD \pm & Min & Max & Mode \\
\hline $\begin{array}{l}\text { Direct labor cost }- \\
\text { preparation }\end{array}$ & 60 & 5.22 & 1.79 & 1.17 & 10.55 & $\ldots$ \\
\hline $\begin{array}{l}\text { Direct labor cost }- \\
\text { administration }\end{array}$ & 60 & 6.37 & 3.82 & 1.49 & 22.08 & $\ldots$ \\
\hline $\begin{array}{l}\text { Direct labor cost - } \\
\text { Total (preparation } \\
\text { and administration) }\end{array}$ & 60 & 11.59 & 4.67 & 5.15 & 28.92 & $\ldots$ \\
\hline Materials' cost & 60 & 37.39 & 13.79 & 17.39 & 76.61 & 25.17 \\
\hline Solutions' cost & 60 & 4.47 & 1.77 & 1.46 & 7.02 & 2.92 \\
\hline Drugs' cost & 56 & 47.1 & 55.07 & 4.54 & 205.36 & 28.54 \\
\hline Total Cost & 60 & 97.41 & 58.13 & 26.29 & 278.47 & $\ldots$ \\
\hline
\end{tabular}


Considering the five stages of the process, there was variation in duration from 25.52 to 78.29 minutes with a mean of 41.98 ( $S D \pm 8.99)$. The average total duration of outpatient drug treatment to women with breast cancer, with the participation of pharmaceutical professional, pharmacy assistant, nurses and nursing technician, was 41.98 minutes ( $\mathrm{SD} \pm 8.99)$.

Table 4 - Distribution of observations relating to all stages of drug treatment under personnel costs, materials, solutions and drugs - São Paulo, SP, Brazil, 2013

\begin{tabular}{lcccccc}
\hline Observations & n & Mean & SD \pm & Min & Max & Mode \\
\hline $\begin{array}{l}\text { Direct labor cost }- \\
\text { preparation }\end{array}$ & 60 & 5.22 & 1.79 & 1.17 & 10.55 & $\ldots$ \\
\hline $\begin{array}{l}\text { Direct labor cost }- \\
\text { administration }\end{array}$ & 60 & 6.37 & 3.82 & 1.49 & 22.08 & $\ldots$ \\
\hline $\begin{array}{l}\text { Direct labor cost }- \\
\text { Total (preparation and } \\
\text { administration) }\end{array}$ & 60 & 11.59 & 4.67 & 5.15 & 28.92 & $\ldots$ \\
\hline $\begin{array}{l}\text { Materials' cost } \\
\text { Solutions' cost }\end{array}$ & 60 & 37.39 & 13.79 & 17.39 & 76.61 & 25.17 \\
\hline Drugs' cost & 56 & 47.1 & 55.07 & 4.54 & 205.36 & 28.54 \\
\hline Total Cost & 60 & 97.41 & 58.13 & 26.29 & 278.47 & $\ldots$ \\
\hline
\end{tabular}

\section{DISCUSSION}

During the period of data collection, the performance of chemotherapy regimens Paclitaxel, Doxorubicin $+\mathrm{Cy}-$ clophosphamide, Trastuzumab and CMF, which are cited in the literature ${ }^{(5)}$ as the most used in the treatment of breast cancer. The regimens FDC and FEC were not observed, due to the low occurrence of its prescription.

Trastuzumab, Paclitaxel and Doxorubicin + Cyclophosphamide were the most important drugs for the composition of the total average cost of the initial stage of the process - separation, preparation and disposal of chemotherapeutics, being the first of higher in unit value ( $R \$$ $8,441.67)$. American study ${ }^{(4)}$ showed that in a 18 month period, medical costs of care for women with metastatic breast cancer were, on average, U\$ 128.556 dollars per patient. In the composition of total costs, the non-chemotherapy drugs and chemotherapy drugs accounted for $26 \%$ and $25 \%$ respectively, showing the significance of expenditures on drugs.

Note that Brazilian study indicated the economic point of view, which restrict the use of Trastuzumab to administration of chemotherapy for early stages would benefit from up to nine times more patients than monotherapy for one year, as used in other protocols. For this comparison, if translated in economic terms, the need to prevent a single value clinically significant outcome: recurrence of breast cancer after three years. Expenses with drugs to prevent a single case of recurrence accounted to just over $\mathrm{R} \$ 418.000,00$ in the most favorable scenario (Trastuzumab concomitant to initial chemotherapy cycles), and between $\mathrm{R} \$ 1.7$ to 3.9 million reais with Trastuzumab monotherapy for one year. However, such values are very significant for countries such as Brazil, where health resources are scarce, access to mammography is precarious and the diagnosis of breast cancer is late ${ }^{(9)}$.

By analyzing the flow of patients treated with breast cancer in public hospitals and employed by SUS, according to the type of treatment received, authors ${ }^{(10)}$ showed that the service was widely distributed throughout the country, with a strong concentration in the larger cities, but with evidence of lack of care even in regions where the supply of services was higher. We highlighted as a challenge to be faced the uneven distribution of population and health services in the country and observed that in tertiary care, the concentration of diagnostic and therapeutic resources imposed extensive shifts to a considerable portion of the population, for example, a large proportion of patients lived more than 150 kilometers from the service location. It was found that approximately half of the municipalities had not submitted any patient for breast surgery in the public network and partner with SUS, $17.8 \%$ did not referr women for chemotherapy and $49 \%$ for radiotherapy ${ }^{(10)}$.

It is clear that women with breast cancer, besides experiencing physical and emotional changes associated with the disease, need to face disparities in access to health care, which is connected to economic constraints.

Thus, considering the demographic, epidemiological and sociocultural distribution of cancer in Brazil, associated with economic factors of the population, we agree that the systematic articulation of care in Oncology, in situations of poverty and low human development constitutes an important challenge for Nursing care ${ }^{(11)}$.

In relation to the materials used in the first stage, the Neutrapur equipment had the highest cost due to its specificity of infusion of certain drugs which, in contact with plastic polyvinyl chloride (PVC), caused detachment of plasticizer of di-2-etilexilftalato. To ensure patient safety, avoiding its exposure to this material, it is recommended the use of bags and catheters of polyolefin plastics (polyethylene or polypropylene) $)^{(6)}$.

In the second stage - disposal pre-medications - the lowest average total cost obtained was related only to the cost of direct labor of the pharmacy assistant.

The costs with curved needles, used to puncture the port-a-cath and venous catheter Intimates ${ }^{\circledR}$, were highlighted when compared to the other materials used in the third stage. In some cases, this device can be implemented before the start of treatment, however, in others, their implementation occurs during treatment, while many women have increasing difficulty of venous access, due to the constant use of the peripheral venous infusion network of chemotherapy. Decadron $10 \mathrm{mg}$ and Ondasentrona $8 \mathrm{mg}$ were the most used pre-medications, however, the Palosentrona, even though it was the least used 
pre-medication, represented the most significant drug in the composition of costs.

In cancer therapy, acute emesis is controlled with the combination of drugs, the choice depends on the expected intensity in accordance with the drugs used in chemotherapy. The degree of emesis of these drugs is given according to the incidence of nausea and vomiting associated with their use $\mathrm{e}^{(12)}$. It is noteworthy that the pharmaceutical industries have developed very effective antiemetics and a longer duration of action but with higher costs, proving why the drugs Zofran and Palosentrona presented sizable values for the average total cost of this stage of treatment.

In the third stage - administration of pre-medications - the time spent by nurses for puncture of the port-a-cath was longer. This type of catheter is common in the chemotherapy infusion, disposal dressings and frequent heparinizations, being even less susceptible to infection and less prone to accidents such as breakage, corrosion and perforation $^{(6)}$. Therefore, due to the specificity and complexity of this type of access, the average time spent is justified by nurses to be higher ( 9.29 minutes) compared to the nursing technician (5.87 minutes), which had only a peripheral venipuncture.

Study ${ }^{(13)}$ developed in a Central Chemotherapy clinic, using the Nursing Intervention Classification ${ }^{(14)}$, showed the time spent of 5.8 minutes to puncture the port-a-cath, which was mapped as an Intervention 2440 keeping device for venous access and 6.3 minutes for venipuncture performed by nurse (Intervention 4190 - venipuncture access).

It is noteworthy that, in the control of tissue perfusion, better skills of nurses for the selection of site for venipuncture have been required, ensuring greater safety in the use of anticancer drugs ${ }^{(13)}$. In this direction, the Outpatient field of study, when the nurse notice a problem in relation to venous access, she/he notifies the oncologist responsible for the patient and, together, decide whether there is an indication of the implementation of central venous catheter.

In the fourth stage - administration of chemotherapeutics - as expected, because it is an exclusive activity of nurses, the cost of the direct labor in this category was the most important variable in the composition of average total cost.

In the fifth step - the withdrawal of venous access and disposal of chemotherapeutic wastes - the anticoagulant heparin was the item that were highlighted in relation to costs. The mean duration of the vascular access and disposal of chemotherapy waste, which could be made by both nurses and nursing technicians, in the case of peripheral venous access, it was higher for nurses. This is because the withdrawal of the central line is the specific activity of the nurse, who before doing it, they perform the heparinization of port-a-cath, resulting in a longer time of action.
Finally, the average total cost per chemotherapy session, comprising the five stages of the process, corresponded to $\mathrm{R} \$ 1,783.01$, being the cost related to drugs $(93.75 \%)$ the most important cost.

The majority (58.33\%) of the observations corresponded to women from the Outpatient Unit for Social Sustainability. According to information obtained from the management of the Hospital Financial Sector, investment related to the comprehensive evaluation of these women, through the Integrated Program for Breast Cancer Control, which is reversed in the tax exemption.

Regarding patients with health insurance, the Hospital open a separate account to the individual in order to document all services and items used to subsidize the bill. Payment from patients with health insurance is determined contractually, being set different fees for the services, together with the values of materials and drugs, composing the total value of chemotherapy.

The transfer of monetary values of SUS to institutions which have chemotherapy for breast cancer in outpatient service can be established through contracting, setting agreed and formalized relationships between managers and providers of health services, or from the values of SIGTAP (System List of Procedures Management, Medicines, Prosthetics and Orthotics, and Specialty Materials - OPM of SUS)(15).

It was not possible to compare the results of the study to the Table of procedures from SUS, because information regarding the staging of the disease in many patients was not obtained, since they arrived at the Outpatient only with a medical prescription, because they have been referred by external physicians. However, the average total cost with respect to the stages studied ( $R \$ 1,783.01$ ) indicates that if the transfer occurred through this table, the values for trading would be related to chemotherapy of advanced breast carcinoma $1^{\text {st }}(R \$ 1,700.00)$ and $2^{\text {nd }}$ ( $R \$ 2,378.90)$ lines.

It is evident that the Ordinance №. $1.703 / \mathrm{GM}^{(16)}$, when providing information for the allocation of resource to encourage contracts of Teaching Public and Private Hospitals, presupposes a set of strategic actions, including: Defining the care profile; the role of the institution and its insertion articulated and integrated with the network of SUS health services; and to define the responsibilities of hospitals and managers in continuing education and training of health professionals and qualification process for hospital management, because of the demands and the insertion of the hospital in regionalized and hierarchical network of SUS.

According to Ordinance № $1606 / \mathrm{GM}^{(17)}$, the manager, state or municipal, may adopt different values of the Procedure Table of SUS, but not below the permitted values which were determined by them to pay for health services, provided that the difference is complemented with 
state and/or municipal resources, being forbidden the use of federal funds for this purpose.

A major challenge in conducting this study was the fact that similar studies have not been found in the literature, which did not allow comparison and discussion of the results.

We also recognize the indispensability of costs of the stage supervision of nurses during infusion of chemotherapy and its lack of observation constituted a limitation of this study. Thus, in an attempt to estimate the value of direct labor to be added to the average total cost per chemotherapy session, we identified as $\mathrm{R} \$ 1,783.01$, a meeting with the nurses in the Outpatient Chemotherapy was held and they, from their experience and clinical experience, reached the consensus that the duration of infusion Paclitaxel, CMF, Doxorubicin and Cyclophosphamide + Trastuzumab corresponded to two hours and 30 minutes, two hours, one hour and 30 minutes and one hour, respectively.

To estimate the average increase in direct labor, the presence of three nurses at the Clinic was considered, on a daily journey of eight hours of work in order to assist an average of ten patients undergoing chemotherapy, regardless of the antineoplastic regimen or combination of drugs. This decision was based on variability in prescription of anticancer regimens or combinations of drugs and the need to include the daily cost of these professionals.

Then, the number of nurses was multiplied by the number of patients per day $(3 \times 8 \times 54.92=R \$ 1,318.08 / 10)$ to give the average increase of $R \$ 131.81$.

It is believed that the study results will assist in the verticalization of discussions of the cost of outpatient drug treatment of women with breast cancer, especially with regard to the reasoning of the professionals involved, with the choice, acquisition and criteria use of materials needed.

Such discussions may facilitate the acquisition and sharing of new knowledge, providing reflections among health professionals about ways of funding SUS and the SHS, the costing methods and principles of strategic cost management, broadening the perspective on the economic factors involved in the care process.

By addressing clinical and economic aspects of adjuvant chemotherapy in HER2-positive breast cancer, the authors claim that the medical profession and society should pay attention not only to the eligibility criteria or differences in efficacy between the various treatment protocols in use, but also, the economic implications of individual therapeutic decisions for the health care system ${ }^{(9)}$.

Knowing the cost of pharmacological treatment generated by this study can provide the professional nursing staff, especially the nurses coordinators and care providers, ele- ments to rethink their practice, since they are in continuous contact with these patients and therefore have a privileged position to assess their real demands of care to the available resources, assisting in cost containment.

It is reiterated that the rising costs related to antineoplastic therapy have been established in the focus of attention of the managers of public and private health systems in order to find alternatives to reduce them. Cost management is, therefore, a key tool for resource control, to help identify more effective and strategic ways to provide administrators the opportunity to identify the most profitable activities, as well as those whose cost need to be analyzed and controlled with utmost care, or activities that are not economically viable ${ }^{(18)}$.

In this view, the professionals who manage hospitals need to develop skills that help them in decision making and resource allocation. To do so, they must determine what resources are needed for the production level of assistance or support from their workplace activities, considering the quantitative/qualitative aspects and adding financial aspects ${ }^{(19)}$.

We agree that the identification of the costs of health services reveals which sectors and actions need to be increased in order to reduce costs, eliminating waste efficiently and preserving the quality of care provided ${ }^{(20)}$.

Finally, we emphasize the importance of the nurse as responsible for the management of materials and their costs in hospitals, as knowledge and means holder for making decisions relating to the care process, based on scientific evidence to support its arguments in relation to the need for spending across the various types of treatment and justify the allocation of human resources to the administration $^{(21)}$.

Knowing the modes of funding, identifying and monitoring elements and process steps that increase costs and that can be removed without loss of quality and without compromising demands, nurses can improve the performance of health institutions. However, while the economics aspects are important, it should not, under any circumstances, overlap technical, ethical and social aspects of human care ${ }^{(22)}$.

\section{CONCLUSION}

The average total cost per session of an outpatient chemotherapy clinic for women with breast cancer was $\mathrm{R} \$ 1,783.01$ (100\%), of which $\mathrm{R} \$ 1,671.66$ (93.75\%) with drugs, $\mathrm{R} \$ 74.98$ (4.21\%) with materials, $\mathrm{R} \$ 28,49$ (1.60\%) with direct labor and $\mathrm{R} \$ \mathrm{7.88}(0.44 \%)$ with solutions.

Considering the specificity of supplies involved in these procedures, it becomes fundamental for nurses, who conducts and supervise much of the therapeutic process, the management of costs, especially due to its high economic impact for public and private health systems.
Procedures costs related to outpatient chemotherapy treatment of women suffering from breast cancer Nobrega CR, Lima AFC 
1. Meropol NJ, Schrag D, Smith TJ, Mulvey TM, Langdon Jr $\mathrm{RM}$, Blum $\mathrm{D}$, et al. American Society of Clinical Oncology guidance statement: the cost of cancer care. J Clin Oncol. 2009;27(23):3868-74.

2. Souza RJSP, Rezende ML, Duarte EM, Mattedi AP, Côrrea MP. Estimativa do custo do tratamento de câncer de pele tipo melanoma no Estado de São Paulo - Brasil. An Bras Dermatol. 2009;84(3):237-43.

3. Martins SJ, Peruna VB. Caracterização dos protocolos de terapia antineoplásica na rede de assistência ambulatorial para os servidores do estado da Bahia, Brasil. Rev Baiana Saúde Pública. 2007;31(2):338-45.

4. Vera-Llonch M, Weycker D, Glass A, Gao S, Borker R, Qin A, et al. Healthcare costs in women with metastatic breast cancer receiving chemotherapy as their principal treatment modality. BMC Cancer. 2011;11:250.

5. Mohallem AGC, Rodrigues AB. Enfermagem oncológica. 2aㅡ ed. Barueri (SP): Manole; 2007.

6. Bonassa EMA, Gato MIR. Terapêutica oncológica para enfermeiros e farmacêuticos. 4ạ ed. São Paulo: Atheneu; 2012.

7. Yin RK. Estudo de caso: planejamento e método. 4a ed. Porto Alegre: Bookman; 2010.

8. Martins E. Contabilidade de custos. 10ạ ed. São Paulo: Atlas; 2010.

9. Martins SJ, Yamamoto CA. Aspectos clínico-econômicos da quimioterapia adjuvante no câncer de mama HER-2 positivo. Rev Assoc Med Bras. 2008;54(6):494-9.

10. Oliveira EXG, Melo ECP, Pinheiro RS, Noronha CP, Carvalho MS. Acesso à assistência oncológica: mapeamento dos fluxos origem-destino das internações e dos atendimentos ambulatoriais. O caso do câncer de mama. Cad Saúde Pública. 2011; 27(2):317-26.

11. Menezes MFB, Camargo TC, Guedes MTS, Alcântara LFFL. Cancer, poverty and human development: challenges for nursing care in oncology. Rev Latino Am Enfermagem [Internet]. 2007 [cited 2013 July 29];15(n.spe):780-5. Available from: http://www.scielo.br/pdf/rlae/v15nspe/10.pdf

12. Consenso Brasileiro de náuseas e vômitos em cuidados paliativos. Rev Bras Cuidados Paliativos. 2011;3(3 Supl.2).

13. Souza CA, Jericó MC, Perroca MG. Nursing intervention/activity mapping at a Chemotherapy Center: an instrument for workload assessment. Rev Latino Am Enfermagem [Internet]. 2013 [cited 2013 July 29];21(2):492-9. Available from: http://www. scielo.br/pdf/rlae/v21n2/0104-1169-rlae-21-02-0492.pdf
14. Dochterman JM, Bulechek GM. Classificação das intervenções de enfermagem (NIC). 4a ed. Porto Alegre: Artmed; 2008.

15. Brasil. Ministério da Saúde. DATASUS. Sistema de Gerenciamento de Tabela de Procedimentos, Medicamentos, Órteses e Próteses e Materiais Especiais - OPM do SUS [Internet]. Brasília; 2013 [citado 2013 jul. 29]. Disponível em: http://sigtap.datasus.gov.br/tabela-unificada/app/sec/procedimento/publicados/consultar

16. Brasil. Ministério da Saúde. Portaria GM n. 1.703, de 17 de agosto de 2004. Destina recurso de incentivo à contratualização de Hospitais de Ensino Públicos e Privados, e dá outras providências [Internet]. Brasília; 2004 [citado 2013 jul. 29]. Disponível em: http://dtr2001.saude.gov.br/sas/PORTARIAS/Port2004/GM/GM-1703.htm

17. Brasil. Ministério da Saúde. Portaria GM n.1606, de 11 de setembro de 2001. Tabela diferenciada para remuneração dos procedimentos do SUS [Internet]. Brasília; 2001 [citado 2013 jul. 29]. Disponível em: http://dtr2001.saude.gov.br/ sas/PORTARIAS/Port2001/GM/GM-1606.htm

18. Oliveira WT, Rodrigues AVD, Haddad MCL, Vannuch MTO, Taldivo MA. Conceptions of nurses from a public university hospital regarding the cost management report. Rev Esc Enferm USP [Internet]. 2012 [cited 2013 July 29];46(5): 1184-91. Available from: http://www.scielo.br/pdf/reeusp/ v46n5/en_21.pdf

19. Lourenço KG, Castilho V. Classificação $A B C$ dos materiais: uma ferramenta gerencial de custos em enfermagem. Rev Bras Enferm. 2006;59(1):52-5.

20. Brasil. Ministério da Saúde; Secretaria Executiva, Área de Economia da Saúde e Desenvolvimento. Avaliação econômica em saúde: desafios para a gestão no Sistema Único de Saúde. Brasília: MS; 2008.

21. Baptista CMC, Castilho V. Cost survey of procedure with Unna boot in patients with venous ulcer. Rev Latino Am Enfermagem [Internet]. 2006 [cited 2013 July 29];14(6): 9449. Available from: http://www.scielo.br/pdf/rlae/v14n6/ v14n6a17.pdf

22. Castilho V, Fugulin FMT, Gaidzinski RR. Gerenciamento de custos nos serviços de enfermagem. In: Kurcgant $P$, coordenadora. Gerenciamento em enfermagem. 2a ed. Rio de Janeiro: Guanabara Koogan; 2010. p.169-80. 